\title{
Correction to: Sonographic follow-up after endoscopic carpal tunnel release for severe carpal tunnel syndrome: a one-year neuroanatomical prospective observational study
}

Miao Li ${ }^{1}$, Jue Jiang ${ }^{1}$, Qi Zhou ${ }^{1}$ and Chen Zhang ${ }^{2^{*}}$

Correction to: BMC Musculoskelet Disord 20, 157 (2019) https://doi.org/10.1186/s12891-019-2548-6

Following publication of this article [1], the authors report the following Corrections to the main text:

i) The authors conducted both studies using data from the same patients. The authors did not reference the related Chinese language article [2]. This citation has been added.

ii) The main differences between the two publications were as followed: First, the two publications did not use the same design. The English language article [1] was designed in early 2014. It was approved by the Ethics Committee of Xi'an Jiaotong university medical college in June 2014 (NO. 2014-003). The period of patient enrollment in this study was from Dec 2014 to Oct 2016. The retrospective study published in Chinese-language article [2] was designed in early 2016 and approved by the Ethics Committee of the second affiliated hospital of Xi'an Jiaotong university in February 2016 (NO.2016-227). The patients in this study were retrospectively analyzed from Dec 2014 to Jan 2016. Second, the statistical analysis between the two articles were different also. Linear mixed model analysis was performed in the English language article [1] and paired $t$-test was used in Chinese language article [2].

Both the original article [1] and the Chinese language article [2] have been updated.

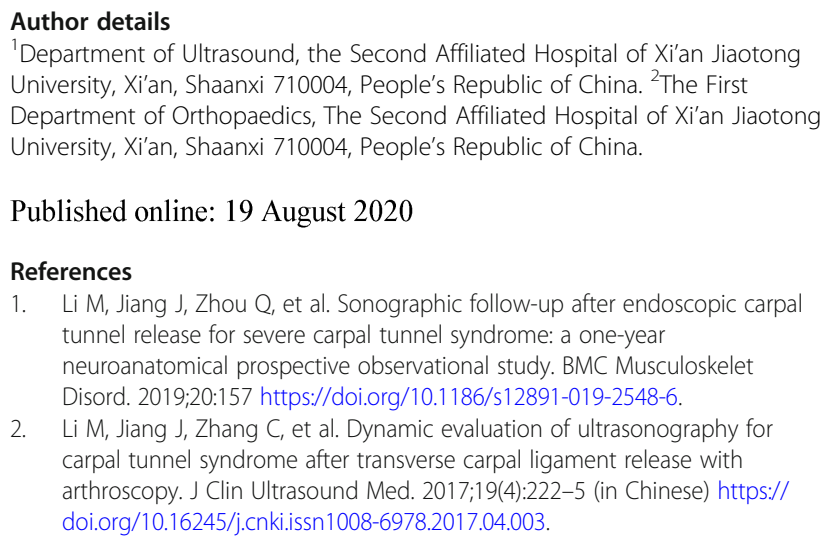

'Department of Ultrasound, the Second Affiliated Hospital of Xi'an Jiaotong University, Xi'an, Shaanxi 710004, People's Republic of China. ${ }^{2}$ The First Department of Orthopaedics, The Second Affiliated Hospital of Xi'an Jiaotong University, Xi'an, Shaanxi 710004, People's Republic of China.

Published online: 19 August 2020

\section{References}

1. Li M, Jiang J, Zhou Q, et al. Sonographic follow-up after endoscopic carpal tunnel release for severe carpal tunnel syndrome: a one-year neuroanatomical prospective observational study. BMC Musculoskelet Disord. 2019;20:157 https://doi.org/10.1186/s12891-019-2548-6.

2. Li M, Jiang J, Zhang C, et al. Dynamic evaluation of ultrasonography for carpal tunnel syndrome after transverse carpal ligament release with arthroscopy. J Clin Ultrasound Med. 2017;19(4):222-5 (in Chinese) https:// doi.org/10.16245/j.cnki.issn1008-6978.2017.04.003

* Correspondence: osteozhang@163.com

${ }^{2}$ The First Department of Orthopaedics, The Second Affiliated Hospital of Xi'an Jiaotong University, Xi'an, Shaanxi 710004, People's Republic of China Full list of author information is available at the end of the article

C The Author(s). 2020 Open Access This article is licensed under a Creative Commons Attribution 4.0 International License, which permits use, sharing, adaptation, distribution and reproduction in any medium or format, as long as you give appropriate credit to the original author(s) and the source, provide a link to the Creative Commons licence, and indicate if changes were made. The images or other third party material in this article are included in the article's Creative Commons licence, unless indicated otherwise in a credit line to the material. If material is not included in the article's Creative Commons licence and your intended use is not permitted by statutory regulation or exceeds the permitted use, you will need to obtain permission directly from the copyright holder. To view a copy of this licence, visit http://creativecommons.org/licenses/by/4.0/. The Creative Commons Public Domain Dedication waiver (http://creativecommons.org/publicdomain/zero/1.0/) applies to the data made available in this article, unless otherwise stated in a credit line to the data. 